\title{
Interest Rate Pass-Through to Macroeconomic Variables: The Nigerian Experience
}

\author{
Adeyemi A. Ogundipe ${ }^{1} \&$ Philip O. Alege ${ }^{1}$ \\ ${ }^{1}$ Department of Economics and Development Studies, College of Development Studies, Covenant University, \\ Nigeria \\ Correspondence: Adeyemi A. Ogundipe, Department of Economics and Development Studies, College of \\ Development Studies, Covenant University, Ota, Ogun State, Nigeria. Tel: 234-81-6192-7372. E-mail: \\ yemi_keke2001@yahoo.com or ade.ogundipe@covenantuniversity.edu.ng
}

Received: August 7, 2013

Accepted: September 5, 2013 Online Published: September 26, 2013

doi:10.5539/ijef.v5n10p18

URL: http://dx.doi.org/10.5539/ijef.v5n10p18

\begin{abstract}
The effectiveness of monetary policy depends on the adjustment response of Central Banks short-term interest rate on the real interest rates charged by commercial banks and ultimately on macroeconomic indicators of investment and consumption in the economy. Thus, the extent of interest rate pass-through largely depends on how effective the process of financial intermediation works and to what extent individual bank characteristics influence or hinder a perfect adjustment of product rates based on market conditions. The study examines the speed and completeness of pass-through from policy rates to retail bank rates and the effectiveness of monetary policy stance in influencing macroeconomic policy targets using a co-integration analysis based on Johansen and Juselius maximum likelihood and Engle-Granger two step procedures for the period 1970-2011. The VAR based Error Correction Model (ECM) and the Mean Adjustment Lag (MAL) was used to determine the short run estimates and asymmetric behaviour respectively. The study found an evidence of downward stickiness both in the short-run and long-run policy pass-through to the retail bank rates. In order to ensure robustness of the result, the Impulse Response Function (IRF) and Variance Decomposition (VD) analysis were conducted and similar slow and sluggish pass-through was obtained. The study as well, found pass-through from policy rate to macroeconomic variables to exhibit extremely rigid immediate responses.
\end{abstract}

Keywords: policy rate, retail bank rate, pass-through, macroeconomic indicators, co-integration

\section{Introduction}

For a long time, official short-term interest rates have been the principal tool of conducting monetary policy for many Central Banks under inflation targeting framework. When the Central Bank changes its official rate, it aims to affect first the money market rate, marginal cost of funds faced by banks, and then the retail (loan and deposits) rates offered by banks to non-financial institutions and households, in order to achieve its aim for inflation and output.

Most Central Banks use short-term interest rates as their main instruments of monetary policy. It is assumed that a change in policy rate will influence interest rates set by commercial banks, which thus stimulate the behaviour of some macroeconomic variables such as investment level of firms, household consumption, and market wage rate. However, this is not usually the case. Commercial banks adjust their interest rates in response to changes in policy rate with lags, which make their interest rates sticky. The stickiness in commercial banks interest rates have been seen as an obstacle to the smooth transmission of monetary policy decisions. Despite the significance of the transmission process, little attention has been given to a systematic measurement of the degree of response of commercial banks' interest rates to changes in monetary policy stance and the dynamics of macroeconomic variable in Nigeria.

The banking sub-sector of the financial system in an economy exercises a vital role in transmitting the monetary policy stance of the Central Bank. A well-functioning banking sector will contribute to economic growth, welfare and smooth business cycles. In addition, they act as conduit pipe through which monetary impulses from the central bank are transmitted to the rest of the economy. According to Fuentes and Ahumada (2003), the activities of banks and their position as intermediaries make them relevant in the transmission process of monetary policy impulses of the central bank to the rest of the economy. An important aspect of the monetary policy transmission 
process is the speed at which changes in policy interest rate is reflected in commercial banks' deposit and lending rates.

The effectiveness of the central bank's monetary policy depends largely on how commercial banks adjust lending and deposit interest rates to changes in the central bank's policy interest rate. The magnitude and speed of these adjustments in the lending and deposit rates determines whether these tools of monetary policy are effective or not. The effectiveness of the central bank's monetary policy is crucial for the stabilization of inflation and as well as other economic activities in the economy, and this largely depends on how commercial banks' interest rates respond to shocks from the central bank's monetary policy rate.

The experience of the world economies with some period of financial crisis has necessitated the investigation of the impact of crisis on the economic structures and monetary policy mechanism. A feasible way of evaluating the performance of monetary policy is through the study of interest rate pass-through (Note 1). High interest rate pass-through implies a close link between monetary policy and the retail banking rate (Note 2). An effective government control of the market rate ensures the economy achieve its policy target while an ineffective or incomplete interest rate pass-through can lead to the failure of monetary policy to stabilize shocks (Tai, Sek \& Har, 2012).

There is overwhelming evidence to show that monetary policy exerts significant influence on national output through aggregate demand. It is also well known in the theoretical literature that the transmission channels of monetary policy, among others, is primarily through interest rate channel. While the earlier studies has extensively provided empirical evidences on the impact of monetary policy stance on retail bank rates (Bernanke \& Blinder, 1992; Christiano et al, 1996; Mallineux, McDonald \& Sensarma, 2007), what has not received adequate attention in the literature is the entire pass-through of monetary policy changes on macroeconomic variables including consumption, investment, saving and inflation.

The major goal of this study therefore, is to explore the effectiveness of the interest rate transmission from policy rate to retail banking rate. It also examines the effect of policy rates on macroeconomic variables such as investment, savings, household consumption, and inflation in Nigeria. It is necessary to note that the assumption that households do not smoothen their consumption which is based theoretical roots of consumption model by Modigliani (1963), Ando and Modigliani (1963) and the permanent income hypothesis by Friedman (1957) (Note 3) is relaxed in this study.

\section{Overview of the Literature}

The concept of interest rate pass-through has drawn extensive attention in literature, most especially in the advanced economies, with limited studies in emerging economies and very few in developing Africa countries (Kashyap \& Stein, 2000; Mojon, 2000; De Bondt, 2005). The essence of estimating how bank prices react to changes in official or market interest rates is motivated by the aim of analyzing how well banks perform as financial intermediaries between general market conditions and final consumer prices (Hofman \& Mizen, 2004; Kleimeier \& Sander, 2006). Furthermore, the speed and extent to which changes in funding costs are passed on to bank customers should be known by banking regulation authorities (Wang \& Lee, 2009; Sander \& Kleimeier, 2004). Thus, in understanding this concept, many studies have focus on the estimation of certain pass-through parameters (Note 4) that describe the interest-setting behaviour of banks (De Bondt, 2005; ECB, 2009; Kwapil \& Scharler, 2010; Liu et al., 2008; Rosen, 2002; Sander \& Kleimeier, 2004).

The pass-through can not only be incomplete in the long run, but also sluggish in the short run. The reasons for this are manifold: First, adjustment or menu costs can cause banks to react sluggishly to changes in the market rates. Second, the maturity mismatch of banks' loan and deposit portfolios influences the way in which they adjusts their lending rates. The more long-term loans are covered by long-term deposits, the less pressure banks feel to adjust their lending rates since their liabilities are less sensitive to market rates (Weth, 2002). Finally, given the long-term relationships of banks (especially universal banks) with their customers, they may want to smooth interest rate changes. The observed price stickiness has necessitated the need to analyze which bank characteristics alter or hinder a complete and rapid product price adjustment following a market interest rate change (De Greave et al., 2007; Ehrmann et al., 2003; Fuertes et al., 2010).

The empirical work of Debondt (2002) using an error correction model based on marginal cost pricing framework for Euro areas found an incomplete pass-through in the short run and a higher complete pass-through in the long run. Other studies in the same region by Cottarelli and Kourelis 1994; Borio and Fritz 1995; Kleimeier \& Sander 2000; Donnay \& Degryse 2001; Toolsema et al., 2000; Hofmann 2000; and Mojon 2000 also found short term sluggishness in the short term bank lending rates but a higher long term pass-through. In the same manner, Kwapil and Scharlar 2009 showed that average long run pass-through of both deposit and 
lending rates appear to be lower in the Euro area than the U.S. Yildrim (2012) estimated the interest rate pass-through to lending rates in Turkey using the threshold co-integration analysis found a downward rigidity of lending rates leading to an incomplete pass-through (Note 5). Likewise, Tobias, Thomas, Ramona and Sonke (2012) (Note 6) found German banks to exhibits sluggish and sticky pricing behaviour.

The results of empirical verification of the effectiveness of policy rates in Asia also featured similar pattern witnessed in the European and North America economies. Tai, Sek and Har (2012) explored the effectiveness of interest rate transmission mechanism in six Asian economies (Note 7) using Seemingly Unrelated Regression (SUR) model for the period 1988-2010 (Note 8). The study found an evidence of slow and sluggish transmission across the countries, high degree of interest rate stickiness or failure of government in controlling the market rate is the possible factors for the slow and small transmission into deposit and lending rates. In a very recent study, Christain and Sebastian (2013) examine the determinants of the effectiveness of interest rate transmission using a panel VAR framework covering 118 countries. The study discovered pass-through to be much lower in developing countries, among which central Asia accounts for the lowest pass-through of about 30 percent while the industrial economies showed a higher pass-through due to more flexibility of exchange rate regime, lower liquidity ratios, better asset quality, and more developed financial system.

Contrary to these studies, Crespo-Cuaresma et al (2004) using the Autoregressive Distributed Lag (ARDL) model to estimate the pass-through from policy rates to lending rate reports that interest rate pass-through tends to be full in the short run. This implies no asymmetric behaviour on the speed of pass-through depending on whether policy interest rate increases or decreases. In this same manner, Rodolfo and Manfred (2008) (Note 9) found no evidence of asymmetric reaction of retail interest rates to movement of policy rate.

Given the importance for monetary policy makers and banking regulation authorities to assess how well the process of financial intermediation works and to what extent individual bank characteristics influence or hinder a perfect adjustment of product rates based on changed market conditions, it is therefore imperative for developing economies to access the effectiveness of financial intermediation and how monetary policy stance affect macroeconomic targets.

\subsection{Factors Affecting the Adjustment of Interest Rates}

The relevance of interest rate pass-through and its significance in the monetary policy transmission process has endeared the attention of economists and policy makers in understanding the manner in which retail interest rates adjust to changes in policy interest rates.

A number of research works seek to investigate the degree and speed of adjustment of banking rates to changes in money market rates. These studies report that changes of retail rate into market interest rate are incomplete and likewise found that the degree and the speed of pass-through vary across countries, especially retail rates. Besides, the rates are very different across countries, which may be due to the macroeconomics or other factors. Among these studies include Borio and Fritz (1995), Cottarelli and Kourelis (1994) (Note 10), Mozzami (1999), Mojon (2000), Kleimeier and Sander (2000), Donnay and Degryse (2001), Toolsema et al. (2002), Espinosa-Vega and Rebucci (2003) and de Bondt (2002). Many studies reveal that interest rate pass-through is sluggish in the short run. The study conducted by Weth (2002), found that pass-through has the tendency to remain sluggish in the short term but it cannot remain incomplete in the long term. One justification for the result include: adjustment or menu costs that can cause banks to react sluggishly towards changes in the market rates. Besides, the maturity mismatches of banks' loan and deposit portfolio impacts on how they adjust their lending rates. Thus, the banks will have less pressure when more long term loans are covered by long term deposits, if their liabilities have less sensitivity towards market rates.

The sluggish adjustment of retail interest rates to changes in policy controlled interest rates has undermined the conduct of monetary policy in most countries. In providing answers to the stickiness of interest rate to policy rate changes, Stiglitz and Weiss (1981) emphasized the role of asymmetric information in credit rationing to explain the stickiness of market rates. In line with Stiglitz and Weiss, Hannan and Berger (1991) and Neumark and Sharpe (1992) identified two sources of asymmetrics distorting the U.S interest rates which include: Collusive pricing arrangements and adverse customer reactions. Studies such as Lowe and Rohling (1992); Cottarelli and Kourelis (1994); Wang and Lee (2009); Fried and Howitt (1980) also provided explanation for the stickiness of interest rates (Note 11). Some of the theoretical evidences for the stickiness of interest rates include: ownership structure of banks, the degree of financial market openness (Borio \& Fritz, 1995), bank concentration, asymmetric information (Stiglitz \& Weiss, 1981), monetary policy regimes (Gidsow 1998; Egert et al 2007), menu cost (Rotemberg \& Saloner, 1987; Hannan \& Berger, 1991; Hofman \& Mizen, 2004), structure of the financial system (Cottarelli \& Kourrlis, 1994), degree of competition (Cottarelli \& Kourrlis, 1994), economic 
policy and regulation (Wang \& Lee, 2009) in the economy are major factors affecting the degree and speed of pass-through from policy rate to lending and deposit rates.

\subsection{The Transmission Mechanism of Interest Rate}

The relevance of the banking sector in the transmission of the central bank's monetary policy stance can be seen via two important channels: the traditional interest rate channel and the credit channel (Note 12). In developing economies, banks and other financial institutions play a key role in the expenditure decisions of firms and households. They serve as the most important alternatives of funding and means of saving, as such, banks and bank behaviour are critical components of the transmission mechanism of monetary policy (Betancourt, Vargas \& Rodriguez, 2006) (Note 13).

Monetary policy becomes effective when the central bank's adjustments to short-term interest rate have an impact on the real interest rates charged by commercial banks to their customers, and, ultimately, on investment and consumption in the economy (Note 14). According to Aziakpono and Wilson (2010), if monetary policy is to be effective, changes in the monetary policy rate should be transmitted to other interest rate quickly, and the magnitude of the change must be large enough to influence investment, consumption and aggregate demand in the economy. According to Aydin 2007; a critical aspect of the monetary policy transmission is the pass-through, which is defined as the degree and speed of adjustment with which a change in monetary policy interest rate is passed on to commercial banks retail interest rates in the economy. If the interest rate pass-through is equal to one, it implies that the interest channel is effective and the IRPT is complete. On the otherhand, if the IRPT is less than one, it implies that the interest rate channel is ineffective and the IRPT is incomplete or sluggish. A high IRPT would suggest a developed, competitive and efficient financial system while a low IRPT suggest the opposite. Also, IRPT can either be long-term or short-term pass-through, in most cases, long-term and short-term IRPT in most advanced economies are often found to be complete. The stickiness of retail interest rates with respect to changes in policy interest rate has been seen as a serious impediment to the smooth transmission of monetary policy impulses to the rest of the economy. It therefore becomes pertinent for central banks and policy makers to have a comprehensive understanding of the nature of IRPT since it can have important implications not only for monetary policy, but to keep track of the level of competition and soundness of the financial system and the entire economy at large (Aydin, 2007; Aziakpono \& Wilson 2010).

There have been literature attention in estimating the adjustment of market rates to policy rate but little focus has been drawn to the impacts of retail rates on economic variables. The study hereby seeks to examine how macroeconomic variables adjust to changes in the official interest rates. Likewise, it seeks to examine how lending and interest rates respond to changes in the official rates and the possibility of convergence among the rates overtime. The study also examines the relative adjustment of commercial bank lending rates to changes in the official rate in case of disequilibrium.

Most monetary policy decision starts with the monetary authorities adjusting the official interest rate. The official policy rates changes for a number of reasons, and one of such reasons might be to stabilize the economy when there is a shock. The short-term official interest rates set by the central bank or the ministry of finance is the main instrument of monetary policy. The central bank frequently exercise its authority by influencing money market condition by an upward or downward review in the policy interest rate which is expected to influence the interbank rate and ultimately retail interest rates and finally influence investment and consumption. This process through which monetary policy is transmitted and ultimately affects inflation and aggregate output is called the monetary policy transmission mechanism (MPTM) (Note 15).

Buiguit (2009) opines that monetary decisions of the central bank rarely work in isolation, they steer economic activities in the economy through monetary transmission channels (Note 16). The effectiveness of these channels depends on the magnitude and speed at which these channels transmit monetary impulses and also depends on factors such as the economic regulation, legal, and financial structure of the economy. In further understanding of the complexity of stages of monetary policy transmission mechanism, Faure (2006) identified six stages which include: (1) change in the central bank's lending rate is transmitted to the private bank-to-bank interbank market (2) the private bank-to-bank interbank market transmits the change to other market interest rates (3) changes in the market interest rates are transmitted to asset prices, exchange rate and expectations (4) the changes in the asset prices, exchange rate and expectation are transmitted to aggregate demand (5) changes in aggregate demand are transmitted to money supply (6) changes in money supply are finally transmitted to prices.

Economy theory suggests that adjustment in the monetary policy actions (Note 17) should influence economic activities in the short or medium term. That is, when central bank changes its monetary policy stance, there should be corresponding changes in retail interest rate for the policy instrument to be effective. But this is hardly 
the situation, as retail interest rate does not necessarily change immediately or experience instant response (one-to-one) with official rates. Mahadeva and Sinclair (2005) provided some insight into the sluggish response of retail interest rates by asserting that the transmission mechanism of monetary policy depends upon how spending decisions of firms and households respond to the interest rate. Likewise, opines that except in the face of strong competition, commercial banks are not interest rate takers in the deposit and loan markets (Note 18). An attempt to understand the mechanism through which monetary policy actions are transmitted to the rest of the economy has led to vast body of theoretical and empirical verification in literature (Bernanke \& Gertler 1995).

A number of literature have identified the need to understand the importance of transmission mechanism and its implication on the developing economies (Ramlogan 2004; Bengnet et al 2007; Scholnick 1996; Samba \& Yan 2010) suggesting that in economies where financial markets are at the early stages of development, the channels of transmission are important for the following reasons; (a) the link between the financial and real sector of an economy is likely to change often in the early stage of development of financial market, hence, it is pertinent to determine the financial aggregates that money policy impacts upon (b) the understanding of MPTM helps policy makers in determining the amount disturbances that warrant changes in monetary policy and which do not (c) knowledge of the transmission mechanism helps promote higher investment and a faster pace of economic growth if it leads to a better choice of target variables.

Understanding monetary policy transmission channels in developing countries has been viewed in two perspective: first is the Mckinnon (1973) and Shaw (1973) view; second is the structuralist view (Note 19). The McKinnon-shaw approach assumes that liberalization of interest rates is crucial since it facilitates the movement of idle resources to more productive use. The approach opines that an increase in interest rates as a result of financial liberalization will increase output and decrease inflation in the short-run, which in turn, boost savings, causing an increasing bank loans to firms, thereby increasing investment and leading to an increase in real output (Taylor 1982; Wijnbergan 1982, 1983). Contrary to the McKinnon approach, the structuralists approach emphasized the effects of financial liberalization in the unorganised money market stressing that financial liberalization policies may lead to an increase in the marginal cost of funds. The results of the increase in the marginal cost of funds (monetary policy tightening) will raise interest rates lending to a drop in the available funds in the informal loan market, causing an increase in marginal cost of funds, thereby lowering investment and decreasing real output (Ghatak \& Sanchez-Fung, 2007). The schematic of the McKinnon-Shaw and structuralists views is as shown below:

McKinnon-Shaw view: $F L \Rightarrow i \uparrow \Longrightarrow S \uparrow \Longrightarrow B L \uparrow \Longrightarrow I \uparrow \Longrightarrow Y \uparrow$

Where FL indicates financial liberalization leading to an increase in interest rates $(i \uparrow)$, which in turn increase financial savings $(S \uparrow)$, causing an increase in bank loans $(B L \uparrow)$, thereby increasing investments $(I \uparrow)$ and real output $(Y \uparrow)$.

Structuralist View: $\quad F L \Rightarrow i \uparrow \Longrightarrow I L M \downarrow \Longrightarrow M C F \uparrow \Longrightarrow I \downarrow \Rightarrow Y \downarrow$

Here, $F L$ indicates financial liberalization will raise interest rate $(i \uparrow)$ leading to a drop in the available funds in the informal loan market $(I L M \downarrow)$ causing an increase in the marginal cost of funds $(M C F \uparrow)$, thereby lowering investment $(I \downarrow)$ and real output $(Y \downarrow)$.

The McKinnon-Shaw approach highlights the main channel of transmission through the direct effect of the controlled interest rates on savings while the structuralist approach emphasizes that interest rates should be market determined (Montiel, 1991).

\section{Dataset and Stylized Facts}

As earlier indicated in the study, the objective of this study is to analyse the interest rate pass-through process in Nigeria by examining the speed and magnitude of the pass-through from Central Bank policy rate to Commercial banks' lending and deposit rates and macroeconomic variables. In order to achieve this, interest rate data series and macroeconomic data such as investment, savings, consumption and inflation are used. The data series on policy rate, lending rate, deposit rate, money supply, output (proxied by GDP) and exchange rate were obtained from World Development Indicators of the World Bank (2012) while data on the investment, savings, household consumption and inflation were extracted from Nation Master Statistics available at www.nationmaster.com. 


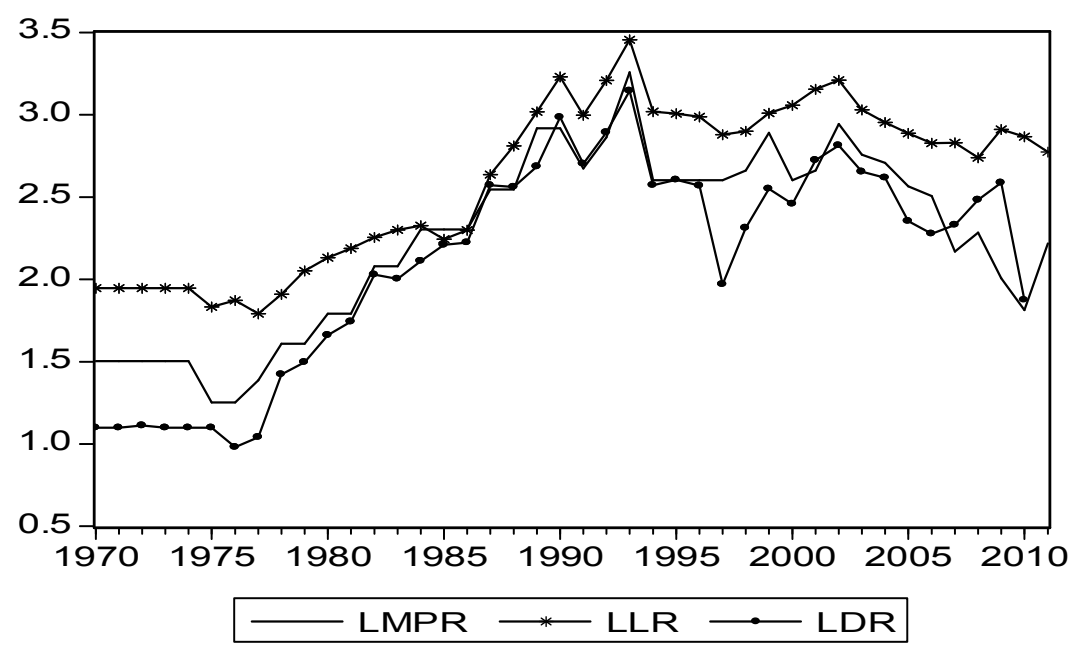

Figure 1. Log trend of retail bank rates and policy rates (1970-2011)

From the figure 1 above, Central Bank policy rate, lending rate and deposit rate appear to follow the same pattern over-time. This shows a long run similar adjustment, implying that changes in the policy rate transmit into the retail bank rates over the period observed. The trend witnessed follows a strand of literature that opines that once a Central Bank policy rate is changed, interbank interest rate follows instantaneously. Central bank often influences the interbank market rate through short-term interest rate since interbank rates respond within a short time horizon to shifts in the central bank policy rate. But in some cases, the response could be incomplete due to bank market power or adjustment cost while it could exceed expectation in some cases.

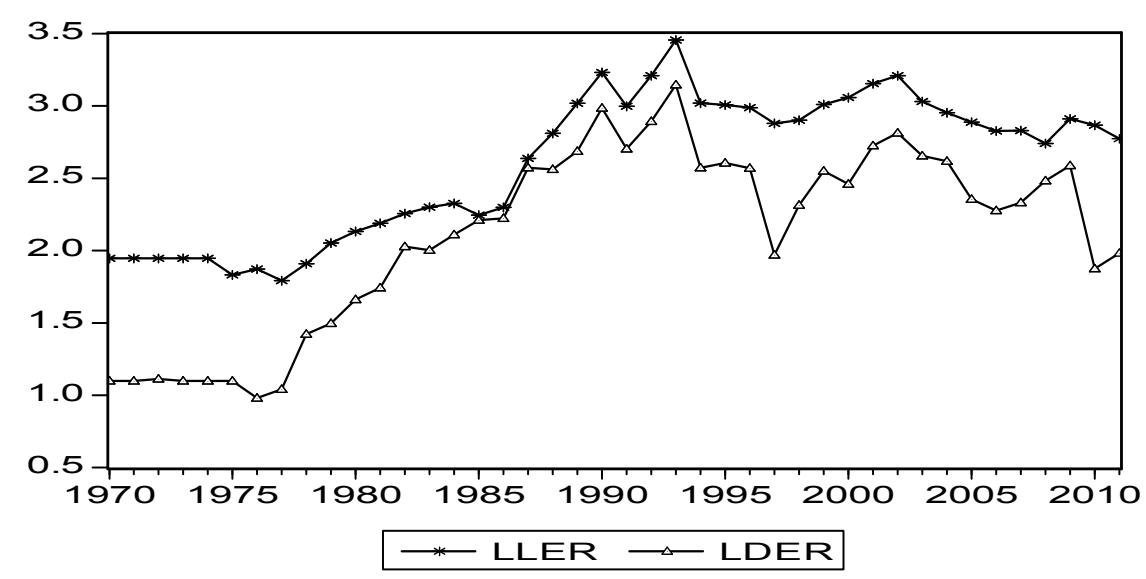

Figure 2. Log trend of commercial banks' lending and deposit rates (1970-2011)

The adjustment of interbank interest rates as a result of changes in policy rate represents an important aspect of interest rate transmission mechanism which heavily depends on the efficiency of the monetary interbank market as a link between monetary policy rate and retail interest rates (Apostoaie, 2007). 


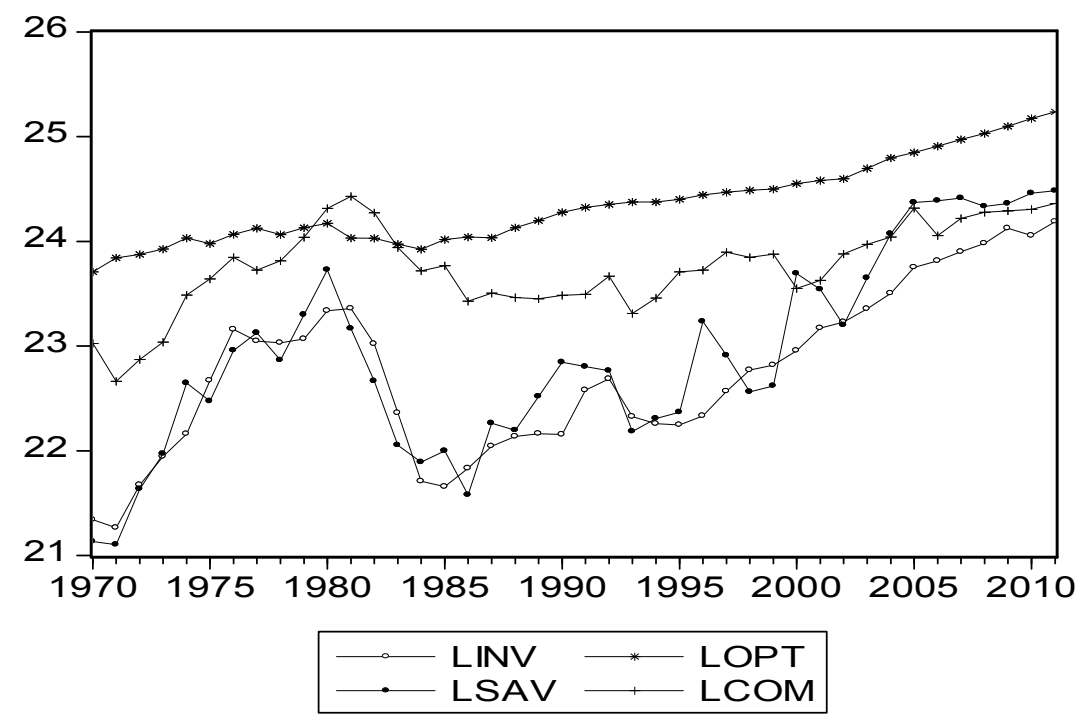

Figure 3. Log trend of investment, savings, output and consumption (1970-2011)

The period of 1970-1985 witnessed an upward trend despite the increasing trend in the policy and retail bank rates. The pattern of movement in the macroeconomic variables took a new pattern in the period 1990-2010. The level of investment has steadily been on the increase from 1990 (figure 3) as the cost of investment (interest rate) begins to dwindle (figure 1). Likewise, output has been on the upward trend similar to pattern exhibited by investment level in the period 1990-2010. In the same manner, output level also maintained an upward trend in the period.
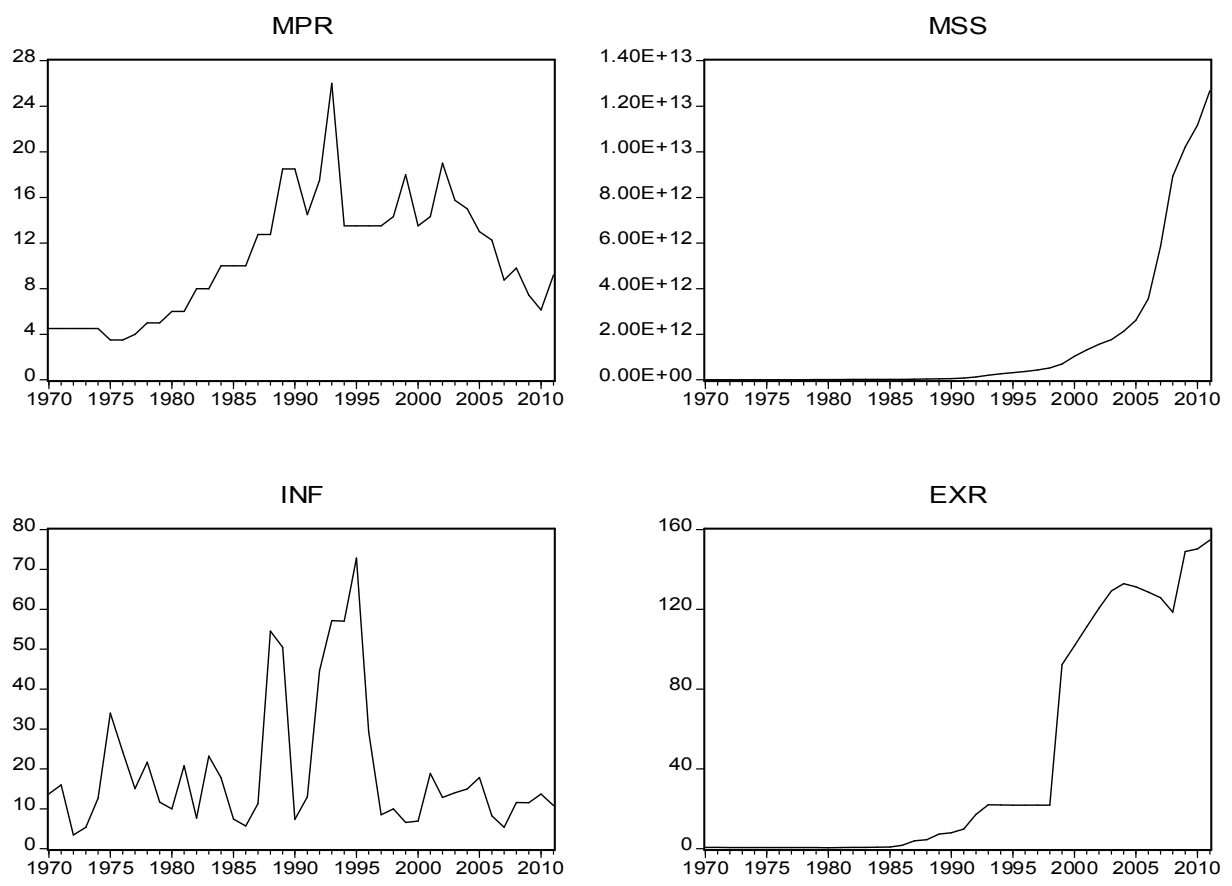

Figure 4. Trend of CB MPR, MSS, INF and EXR (1970-2011) 
A careful examination of figure 4 reveals that as Central Bank adjust its policy rate downward or adopt an expansionary policy; it culminates into fall in retail bank rates which encourage demand for bank loans. The greater incentive to borrow from commercial banks due to lower lending rate increases the volume of money in circulation and cause exchange rate to depreciate. The value of other currencies rises with respect to the naira, as excess money supply increases the taste and demand for foreign goods and services.

\section{Methodology}

\subsection{Model Specification}

This paper adopts the monetary policy approach which controls for the availability of connection between policy interest rate and bank retail interest rates. The relationship between money market and retail rates is explained through the marginal cost pricing model proposed by Bondt (2002). The model assumes perfect competition with complete information and equality of prices with marginal costs. Likewise, the derivative of prices with respect to marginal cost equals one but becomes less than one if the perfect competition and information prices are suspended (Tai, Sek, \& Har, 2012; Rousseas 1985).

Applying the concept to the price setting of banks, the model is represented as follows:

$$
b r=\gamma_{0}+\gamma_{1} m r+\varepsilon_{t}
$$

Where $b r$ is the retail bank rate (Note 20), $\gamma_{0}$ is a constant mark up and $m r$ is the marginal cost price which is proxied by the monetary policy rate and $\gamma_{1}$ is the coefficient of pass-through rate (Note 21). There is a complete pass-through if $\gamma_{1}=1$, and incomplete when $\gamma_{1}$ is less than one. $\gamma_{1}$ is less than one when banks possess some degree of market power (Note 22). The factors that are likely to influence market forces include switching cost, asymmetric information and restricted entry to the banking sector creating a precondition for high degree of market power (Niggle, 1987). This study likewise seeks to estimate the pass-through of policy rate into the banking lending rates and deposit rates. The transmission processes shall be considered under the short-run and long-run.

$$
\begin{gathered}
l r=\alpha_{0}+\alpha_{1} m r+\varepsilon_{1 t} \\
d r=\beta_{0}+\beta_{1} m r+\varepsilon_{2 t}
\end{gathered}
$$

where $l r$ indicates lending rate, $d r$ is the deposit rates, $m r$ is the monetary policy rate and $\varepsilon_{1 t}$ and $\varepsilon_{2 t}$ is the stochastic random term.

\subsubsection{Pass-Through to Macroeconomic Variables}

Contrary to earlier studies on the subject, this study proceed to access the effect of policy rate on major macroeconomic variables; this is deemed necessary to ascertain the effectiveness of monetary policy stance of the monetary authorities on policy targets of the economy. The pass-through effect of monetary policy rates is evaluated on macroeconomic variables such as investment, saving, household consumption and inflation.

The study assumes a Keynesian model where desired investment is determined by level of interest rate (Note 23); and represented as follows:

$$
\operatorname{mac}_{k, t}=f\left(m p r_{t}, m s_{t}, \operatorname{exr}_{t}, y d_{t}, y d_{t+1}\right)
$$

This can be rewritten under the assumption of linearity as follows:

$$
m a c_{k, t}=\theta_{0}+\theta_{1} m p r_{t}+\theta_{2} m s_{t}+\theta_{3} \operatorname{exr}_{t}+\theta_{4} y d_{t}+\theta_{5} y d_{t+1}+\mu_{t}
$$

Where $\mathrm{mac}_{k, t}$ is a vector of macroeconomic variables including investment, savings,

inflation and household consumption. $\operatorname{mac}_{k, t}=\left(i n v_{k, t} \operatorname{sav}_{k, t} \inf _{k, t} \operatorname{com}_{k, t}\right)^{\prime}$ such that $k=1, \ldots, 4 . m p r_{t}$ is the central bank monetary policy rate, $m s_{t}$ is the broad money supply, exr $t_{t}$ is the exchange rate, $y d_{t}$ is the current output level and $y d_{t+1}$ is the expected future output level.

\subsection{Techniques of Estimation}

The study adopts a co-integration approach based on the Johansen and Juselius (1980) and Engle and Granger (1987) approach. This is necessary as many financial variables are non-stationary but tend to move together over time Brooks (2008). The presence of co-integration among variables suggests the existence of a long run relationship and absence of co-integration suggest no long run relationship. The essence of the test is to verify if co-integration relationship exists and as well determine the number of co-integrating vectors. The starting point of interest rate pass-through analysis in estimating the short-run error correction model as well as the long-run co-integrating vector can be presented in an equation similar (1) above.

$$
Y_{t}=\beta_{0}+\beta_{1} x_{t}+\varepsilon_{t}
$$


Where $Y_{t}$ indicates the endogenously determined retail rates (lending and deposit) of commercial banks, $x_{t}$ is the exogenously determined central bank monetary policy rate, $\beta_{0}$ and $\beta_{1}$ are the intercept and long run parameter respectively and $\varepsilon_{t}$ is the stochastic error term.

The empirical model of interest rate pass-through based on co-integration methodologies can be specified as follows:

$$
B R_{t}=\beta_{0}+\sum_{i-1}^{K^{*}} \beta_{B R, i} B R_{t-i}+\beta_{1} M R_{t}+\sum_{i-1}^{n^{*}} \beta_{M R, i} M R_{t-i}+u_{t}
$$

Where $B R_{t}$ denotes the retail bank rates, $M R_{t}$ represents the central bank policy rates, $k^{*}$ and $n^{*}$ indicate the optimal lag lengths determined using the AIC criterion, allowing for a maximum of four lags (Sander \& kleimeier, 2006), $\beta_{0}$ represents the intercept or the credit risk premium (Note 24), $\beta_{1}$ is the impact multiplier and $u_{t}$ is the error term. The impact multiplier $\beta_{1}$ measures the immediate adjustment in retail rates in response to changes in the policy rate; where $\beta_{1}<1$ it indicates sluggish adjustment (Note 25), if $\beta_{1}=1$, then the immediate pass-through is complete and monetary policy is effective. It is necessary to note that the equation (6) above is applicable for data series are stationary at levels but if series are found to be non-stationary we can then proceed to estimate the empirical pass-through model of first difference in order to avoid spurious regression.

$$
\Delta B R_{t}=\beta_{0} \sum_{i-1}^{k^{*}} \beta_{B R, i} \Delta B R_{t-i}+\beta_{1} \Delta M R_{t}+\sum_{j-1}^{n^{*}} \beta_{M R, j} \Delta M R_{t-j}+\varepsilon_{t}
$$

Where $\Delta$ represents the first difference operator of lending and deposit rates $k^{*}$ and $n^{*}$ are lag lengths, $\beta_{0}$ and $\beta_{1}$ are the short run intercept and slope coefficient respectively. By estimating vii the problem of spurious regression is avoided but information about the long run relationship will be lost. However, following specification from Kwapil and Scharlar (2010), the long run pass-through can be computed via.

$$
\theta=\frac{\left(\sum_{i=0}^{k} \beta_{1}\right)}{\left(1-\sum_{j=0}^{n} \beta_{B R, i}\right)}
$$

From the above expression, $\beta_{B R, i}$ represents the coefficient of the retail rates, $\beta_{1}$ is the coefficient of policy rate. Where $\theta=1$, it implies full pass-through and where $\theta>1$ there is incomplete pass-through.

\subsubsection{Equilibrium Error Correction Model}

This attempts to adjust the disequilibrium in a co-integrating relationship. This is based on the logic that a long run relationship exists and that there are disturbances in the short-run which needs adjustment back to long run equilibrium (Note 26). According to Engle and Granger (1987) (Note 27) "an error correction model for a two variable system would relate the change in one variable to past equilibrium errors as well as to past changes in both variables". If such co-integrating relationship is found, then the error correction model with augmented lag values of the error term as specified below is estimated:

$$
\Delta B R_{t}=\beta_{0} \sum_{i-1}^{k^{*}} \beta_{B R, i} \Delta B R_{t-i}+\beta_{1} \Delta M R_{t}+\sum_{j-1}^{n^{*}} \beta_{M R, j} \Delta M R_{t-j}+\beta_{E C T} E C T_{t-1}+\varepsilon_{t}
$$

Where $\Delta$ denotes the first difference operator, $\beta_{E C T}$ represents the coefficient of the error correction term (Note 28) $E C T_{t-1}$ measures the speed of adjustment back to equilibrium.

\subsubsection{Mean Adjustment Lag: Symmetric and Asymmetric Error Correction Framework}

After estimating the short run and speed adjustment coefficients from the equation above; the next step is to ascertain how long it would take the retail rates to return to long run equilibrium; this would lead to estimating the Mean Adjustment Lag (MAL). In similar estimation procedure, Doornick and Henry (1994); Scholnick (1996); and Fomum (2011), the mean adjustment lag is expressed as:

$$
M L=\left(1-\beta_{1}\right) / \beta_{E C T}
$$

The empirical study of Scholnick (1996) (Note 29) suggested an alternate method of estimating the MAL (Note 30 ) is to divide the residual obtained from the co-integration regression into $E C^{+}$and $E C^{-}$representing the error term when the residuals are above and below their equilibrium levels respectively. This is represented as follows

$$
\begin{gathered}
E C^{+}=E C \text { if } E C>\mu \\
E C^{+}=0 \text { if } E C<\mu \text { and } \\
E C^{-}=E C \text { if } E C<\mu \\
E C^{-}=0 \text { if } E C>\mu
\end{gathered}
$$

Where $\mu$ is the mean of the residuals (EC). The asymmetric specification in equations 10 and 11 are then 
included as separate dummy variables into (8) to derive the short run asymmetric dynamic equation as

$$
\Delta B R_{t}=\beta_{0}+\beta_{1} \Delta M R+\varphi_{i} \sum_{i-1}^{k^{*}} \Delta M R_{t-i}+\lambda_{j} \sum_{j-i}^{n^{*}} \Delta B R_{t-j}+\delta_{1} E C_{t-1}^{+}+\delta_{2} E C_{\bar{t}-1}^{-}+\varepsilon_{t}
$$

Where $\delta_{1}$ and $\delta_{2}$ indicate the coefficients of the error correction terms when lending and deposit rates are beyond or below their equilibrium respectively, from 7 , the MAL is defined as

$$
\begin{aligned}
& M L^{+}=\left(1-\beta_{1}\right) / \delta_{1} \\
& M L^{-}=\left(1-\beta_{1}\right) / \delta_{1}
\end{aligned}
$$

We can then test the asymmetric adjustment by using the Wald test- $\chi^{2}(1)$ by imposing restriction that $\delta_{1}=\delta_{2}$, and if $\delta_{1}=\delta_{2}$ we cannot reject the null hypothesis of no asymmetry. Therefore, we conclude that there is no evidence of asymmetry adjustment.

\section{Empirical Analysis and Result Discussion}

The empirical investigation of the effectiveness of policy rates on retail bank rates in Nigeria begins with the empirical analysis verification of the time series property of the variables in the model. This implies testing whether the interest rates series are stationary at level or at first difference using the Augmented Dicky-fuller (ADF) and Philip Perron tests. From the results available from table 1, we failed to reject the null hypothesis of unit root (non-stationarity) which suggest all the variables are non-stationary at level; except money supply and current output level. Asides the these two variables that become stationary at levels, the rest of the variables are stationary at first difference, that is, I(1).

Table 1. Unit root test

Computed by authors using Eview 5.0.

\begin{tabular}{ccccc}
\hline \multicolumn{4}{c}{ Unit Root Test } \\
\hline \multicolumn{4}{c}{ Level } & \multicolumn{2}{c}{ First difference } \\
Variables & ADF & PP & ADF & PP \\
Ler & -1.6538 & -1.6189 & $-7.0266^{*}$ & $-7.0396^{*}$ \\
Der & -1.7091 & $-1.9444^{* *}$ & $-3.2264^{*}$ & $-8.0682^{*}$ \\
Mpr & -2.1322 & -1.9304 & $-6.8082^{*}$ & $-8.8617^{*}$ \\
Inv & 1.3295 & 0.9747 & $-4.1427^{*}$ & $-4.1520^{*}$ \\
Sav & -0.0068 & 0.1278 & $-5.5428^{*}$ & $-5.4931^{*}$ \\
Com & -1.4159 & -1.4159 & $-5.7432^{*}$ & $-5.7522^{*}$ \\
Mss & $6.5067^{*}$ & $5.6988^{*}$ & $3.2850^{*}$ & -1.4135 \\
Exr & 0.5662 & 0.5447 & $-5.8775^{*}$ & $-5.8764^{*}$ \\
Otp & $4.3054^{*}$ & $4.8148^{*}$ & 0.1139 & $-3.3844^{* *}$ \\
\hline
\end{tabular}

In ensuring the robustness of our results, two different co-integration test techniques were adopted. The study conducted a test of co-integrating relationship based on the Johansen and Joselius maximum likelihood test and the Engle-Granger two step procedure, the JJ and EG test rejected the null hypothesis of no co-integration between retail bank rates and Central Bank policy rate, indicating a stable long run relationship between retail

\begin{tabular}{|c|c|c|c|c|c|c|c|c|c|c|c|}
\hline & \multicolumn{2}{|c|}{ Period } & \multicolumn{2}{|c|}{ Cointegration } & \multicolumn{2}{|c|}{ Long run PT } & \multicolumn{2}{|c|}{ Short run PT } & \multicolumn{2}{|c|}{$\mathbf{E C T}_{\mathrm{t}-1}$} & \multirow[t]{2}{*}{ ML } \\
\hline & from & To & $\overline{\mathrm{JJ}}$ & EG & coff & t.stat & coff & t.stat & coeff & t.stat & \\
\hline Lending rate & 1970 & 2011 & YES & YES & 0.70 & 7.6 & 0.72 & 6.5 & -0.19 & -0.9 & -1.5 \\
\hline Deposit rate & 1970 & 2011 & YES & YES & 0.68 & 6.76 & 0.65 & 6.1 & -0.28 & -1.5 & -1.3 \\
\hline
\end{tabular}
and policy rates.

Table 2. Summary of pass-through

Computed by authors using Eview 5.0.

\subsection{Short Run and Long Run Pass-Through}

The short run pass-through (Note 31) measures the contemporaneous reaction of commercial banks to a change in the policy rates of the central bank. This measures how immediate a change in the policy rate is transmitted to the real economy via the retail rates adjustment by commercial banks. The extent of this impact multiplier of the policy rate indicates the effectiveness of the monetary policy. According to Fomum (2011) "..... a short run 
coefficient of one or close to one means pass-through is faster or rapid and hence monetary policy is said to be effective, and less than one means otherwise. In addition, an extreme case may occur when the short run coefficient is more than one. In such a situation, we say that the short run pass-through overshot".

The estimated coefficient from table 2 reveals that the immediate pass-through is faster for lending rate $(0.72)$ than for the deposit rate $(0.65)$ in Nigeria. however, despite the higher pass-through for lending rate, the overall pass-through is sluggish in the short-run. In the case of long run, there exists a slower and more sluggish pass-through for lending (0.70) than in the short run and a slow pass-through is witnessed for deposit rate. Overall, the long run pass-through is sluggish or incomplete. This evidence partly contrast the empirical evidence of Fomum (2011) which found though an incomplete pass-through but a faster long run pass-through for lending rate in Nigeria. Likewise, it contrast the empirical works of Cottarelli and Kourelis (1994); Borio and Fritz (1996P; Kleimeier \& Sander (2000); Donnay \& Degryse (2001); Tobia et al (2012); and Yildrim (2012) which all found a sluggishness in the short term pass-through of bank lending rates but a complete long term pass-through. The experienced sluggishness in the long run pass-through in Nigeria must have resulted from the developing status of our financial system.

Table 3. Summary of asymmetric pass-through

\begin{tabular}{cccc}
\hline & & Lending rate & Deposit rate \\
\cline { 2 - 4 } Period & From & 1970 & 1970 \\
& To & 2011 & 2011 \\
& coeff & -0.17 & -0.14 \\
$E C T_{t-1}^{+}$ & t.stat & -3 & -2.5 \\
& coeff & -0.06 & -0.02 \\
& t.stat & -0.82 & -0.34 \\
Wald test & t.stat & 0.93 & 1.73 \\
& $\mathrm{PV}$ & 0.34 & 0.19 \\
Mean Lag & $\mathrm{ML}^{+}$ & -1.87 & -3.42 \\
PT mechanism & $\mathrm{ML}^{-}$ & -5.1 & -26.71 \\
Adjustment rigidity & & symmetric & symmetric \\
& & downward & Downward \\
\hline
\end{tabular}

Computed by authors using Eview 5.0.

The error correction mechanism $\left(\mathrm{ECT}_{\mathrm{t}+1}\right)$ shows that about $19 \%$ of the error encountered in the short run (disequilibria) in the credit market are corrected every month. Thus, implying $19 \%$ of short run disturbances are adjusted back to equilibrium or stationary path in the long run. Likewise, about $28 \%$ of short run disturbances are adjusted to equilibrium path per month by forces in the deposit market. This evidence indicate that the speed of error correction is weak, therefore disturbances in the model is long-lived.

The extent of pass-through can also be access using Impulse response function (IRF) and variance decompositions (VD). The IRF traces out the effect over time on rates of a structural one standard deviation shock to the policy rate. The variance decompositions break down the forecast variance of retail bank rates into components that can be attributed to each of the various shocks in the system. It allows us, therefore, to examine the relative importance of various shocks for fluctuations in retail prices. The pass-through to retail rates over $T$ periods is defined as the accumulated effect of a structural one standard deviation shock to policy rate in period $T$ on bank rates in period $T$.

The table below shows the accumulated response of retail bank rates to a structural one standard deviation shock to policy rate. The result indicates an evidence of pass-through with the immediate effect of a shock to policy rate at a period (say period 3) leading to about $0.83(83 \%)$ and $0.15(15 \%)$ in lending and deposit rates respectively. also, there is an evidence of incomplete pass-through as the horizon expands (Note 32) as the full effect of policy changes is not fully exhausted by the retail bank rates. 
Table 4. Accumulated responses of retail bank rates

\begin{tabular}{ccccc}
\hline \multicolumn{3}{l}{ Lending rate } & \multicolumn{2}{l}{ Deposit rate } \\
\hline Period & DLER & DMPR & DDER & DMPR \\
1 & 2.9765 & 0.0000 & 2.9887 & 0.0000 \\
2 & 2.5035 & -0.5139 & 2.0297 & -0.0386 \\
3 & 2.0472 & -0.8375 & 1.5085 & -0.1551 \\
$:$ & $:$ & $:$ & $:$ & $:$ \\
7 & 2.2714 & -0.5194 & 1.8711 & -0.0750 \\
$:$ & $:$ & $:$ & $:$ & $:$ \\
10 & 2.2769 & -0.5318 & 1.8743 & -0.0746 \\
$:$ & $:$ & $:$ & $:$ & $:$ \\
12 & 2.2805 & -0.5322 & 1.8799 & -0.0729 \\
\hline
\end{tabular}

Computed by authors using Eview 5.0.

Likewise, the evidence from the variance decomposition supports the IRFs, as the immediate effect of a shock in policy rate would lead to about $6 \%$ and $3 \%$ change in lending and deposits rate respectively. This as well, indicates a sluggish and incomplete pass-through, though pass-through improves as the horizon expands.

Table 5. Variance decomposition of retail bank rates

\begin{tabular}{ccccc}
\hline \multicolumn{4}{c}{ Lending rate } & \multicolumn{2}{c}{ Deposit rate } \\
\hline Period & DLER & DMPR & DDER & DMPR \\
1 & 100.0000 & 0.0000 & 100.000 & 0.0000 \\
2 & 97.1744 & 2.8256 & 99.9849 & 0.0152 \\
3 & 96.1814 & 3.8186 & 99.8515 & 0.1485 \\
$:$ & $:$ & $:$ & $:$ & $:$ \\
7 & 94.0933 & 5.9067 & 99.7317 & 0.2683 \\
$:$ & $:$ & $:$ & $:$ & $:$ \\
10 & 94.0854 & 5.9146 & 99.7301 & 0.2699 \\
$:$ & $:$ & $:$ & $:$ & $:$ \\
12 & 94.0849 & 5.9151 & 99.7300 & 0.2700 \\
\hline
\end{tabular}

Computed by authors using Eview 5.0.

The Johansen and Joselius maximum likelihood test and the Engle-Granger two step procedure co-integration tests the null hypothesis of no co-integration in the four functions examined (investment, consumption, savings and inflation). It therefore, implies an evidence of stable long run relationship between Central Bank policy rate and the explained variable(s).

Table 6. Pass-through to macroeconomic variables

\begin{tabular}{ccccccccccc}
\hline & \multicolumn{2}{c}{ Period } & \multicolumn{2}{c}{ Cointegration } & \multicolumn{2}{c}{ Long run PT } & \multicolumn{2}{c}{ Short run PT } & \multicolumn{2}{c}{ ECT $_{\text {t-1 }}$} \\
\hline & from & To & JJ & EG & Coff & t.stat & coff & t.stat & coeff & t.stat \\
Investment & 1970 & 2011 & YES & YES & 0.02 & 2.1 & 0.03 & 2.7 & 0.76 & -0.9 \\
Consumption & 1970 & 2011 & YES & YES & 0.03 & 1.7 & 0.04 & 2.1 & 0.04 & 0.25 \\
Savings & 1970 & 2011 & YES & YES & 0.008 & 0.83 & 0.01 & 1.4 & 0.07 & 0.42 \\
Inflation & 1970 & 2011 & YES & YES & 0.21 & 0.27 & 0.77 & 0.89 & 0.08 & 0.49 \\
\hline
\end{tabular}

Computed by authors using Eview 5.0.

The estimated results from the table above reveals that immediate pass-through is weak (extremely slow and sluggish) for investment, consumption, savings and inflation. Likewise, the long run pass-through exhibits similar trend with the short run. The error correction shows that about $76 \%, 4 \%, 7 \%$ and $8 \%$ of short run disturbances are adjusted back to equilibrium path every month. 


\subsection{Interpretation of Long-Run Estimates}

\subsubsection{Investment Function}

The Johansen and Joselius maximum likelihood estimation was used to obtain the long run estimates. The indicator of Central Bank policy rate exerts an inelastic and significant variation on level of investment, thus implies that a proportionate change in policy rates results in less than proportionate change in the level of investment. This thereby depicts the reality in the developing Africa, as demand for loan is often inelastic due to lack of alternative form of financing. In panel (b), we interacted lending rate with investment while restricting policy rate; the result obtained was similar to the impact of policy rate. Likewise, expected future output was found to exert an elastic and significant impact on level of investment. A proportionate change in expected future output results in more than proportionate change in investment. This is consistent with economic theory as an expectation of increased future output enhances current level of investment.

\subsubsection{Consumption Function}

The result available from the panel (a) shows that indicator of Central Bank policy rate exerts an inelastic and significant impact on household consumption, implying that a proportionate change in policy rate results in less than a proportionate change in household consumption. The expected future output also exerts a significant elastic variation on household consumption. In panel (b) and (c), lending rate and deposit rate were interacted distinctly with household consumption and both impact though inelastic but a significantly on household consumption.

Table 7. Johansen and Juselius long run estimates

\begin{tabular}{|c|c|c|c|c|c|}
\hline \multicolumn{3}{|c|}{ Investment Function } & \multicolumn{3}{|c|}{ Consumption Function } \\
\hline \multirow{3}{*}{$\begin{array}{c}\text { Variable } \\
\text { dmss }\end{array}$} & (a) & (b) & (a) & (b) & (c) \\
\hline & $-1.91 \mathrm{e}-13$ & $1.15 \mathrm{e}-13$ & $1.93 \mathrm{e}-12$ & $9.17 \mathrm{e}-13[$ & $6.67 \mathrm{e}-14$ \\
\hline & {$[-1.16]$} & {$[0.97]$} & {$[2.38]$} & $1.69]$ & {$[1.10]$} \\
\hline \multirow{2}{*}{ dexr } & 0.0046 & 0.0013 & 0.0079 & 0.00692 & 0.0055 \\
\hline & {$[0.44]$} & {$[0.16]$} & [1.95] & {$[2.53]$} & {$[1.80]$} \\
\hline \multirow[t]{2}{*}{ dmpr } & -0.2850 & - & 0.1407 & - & - \\
\hline & $\begin{array}{c}{[-5.45]} \\
-\end{array}$ & -0.1099 & $\begin{array}{c}{[9.07]} \\
-\end{array}$ & 0.0543 & - \\
\hline dler & & {$[-3.01]$} & & {$[4.77]$} & \\
\hline dder & - & - & - & - & $\begin{array}{l}0.0915 \\
{[6.82]}\end{array}$ \\
\hline dlopt & - & - & $\begin{array}{c}-0.7077 \\
{[-0.08]}\end{array}$ & $\begin{array}{c}-0.1208 \\
{[-0.19]}\end{array}$ & $\begin{array}{c}-0.0610 \\
{[-0.09]}\end{array}$ \\
\hline \multirow{2}{*}{ dlopt $_{t+1}$} & -4.7247 & -6.9769 & -2.269 & -3.7406 & -2.0969 \\
\hline & {$[-1.89]$} & {$[-3.72]$} & {$[-2.32]$} & {$[-5.69]$} & {$[-2.84]$} \\
\hline $\mathrm{C}$ & 0.2909 & -0.4060 & -0.1981 & -0.1311 & \\
\hline
\end{tabular}

Computed by authors using Eview 5.0.

\subsubsection{Inflation Function}

The estimates from table below in panel (a) indicate that policy rate exerts elastic and significant variation on inflation; that is, a proportionate change in policy rate results in more proportionate change in inflation. This is consistent with theory as the level inflation can be targeted using monetary authorities policy tools. The policy rate exerted the largest variation on inflation, hereby making it a useful instrument for monetary authorities under inflation target regime. Also, the expected future exerts an elastic variation on inflation rate implying that an expectation of a leap in future output tends to reduce the level of inflation. In panel (b), policy rate was restricted and lending rate imposed, the lending rate exhibited similar trend with the policy rate, that is, it exerts elastic and significant variation on inflation. 
Table 8. Johansen and Joseliuslong run estimates

\begin{tabular}{|c|c|c|c|c|c|}
\hline \multicolumn{3}{|c|}{ Inflation Function } & \multicolumn{3}{|c|}{ Savings Function } \\
\hline Variable & (a) & (b) & (a) & (b) & (c) \\
\hline dmss & $\begin{array}{c}-1.79 \mathrm{e}-11 \\
{[-1.25]}\end{array}$ & $\begin{array}{c}4.51 \mathrm{e}-14 \\
{[0.01]}\end{array}$ & $\begin{array}{c}2.16 \mathrm{e}-13 \\
{[3.29]}\end{array}$ & $\begin{array}{c}2.00 \mathrm{e}-13 \\
{[2.98]}\end{array}$ & $\begin{array}{c}1.95 \mathrm{e}-13 \\
{[2.83]}\end{array}$ \\
\hline dexr & 0.0682 & 0.1547 & -0.0061 & -0.0064 & -0.0058 \\
\hline & {$[0.10]$} & {$[0.52]$} & {$[-1.85]$} & {$[-1.88]$} & {$[-1.67]$} \\
\hline dmpr & $\begin{array}{c}-26.5908 \\
{[-9.68]}\end{array}$ & - & $\begin{array}{l}0.0249 \\
{[1.98]}\end{array}$ & - & - \\
\hline dler & - & $\begin{array}{c}-8.9388 \\
{[-7.26]}\end{array}$ & - & $\begin{array}{l}0.0165 \\
{[1.17]}\end{array}$ & - \\
\hline dder & - & - & - & - & $\begin{array}{c}-0.0102 \\
{[-0.67]}\end{array}$ \\
\hline dlopt & $\begin{array}{l}-16.693 \\
{[-0.10]}\end{array}$ & $\begin{array}{c}-3.7649 \\
{[-0.06]}\end{array}$ & $\begin{array}{l}0.3641 \\
{[0.48]}\end{array}$ & $\begin{array}{l}0.3606 \\
{[0.47]}\end{array}$ & $\begin{array}{l}0.3631 \\
{[0.46]}\end{array}$ \\
\hline dlopt $_{t+1}$ & $\begin{array}{c}-370.673 \\
7 \\
{[-2.14]}\end{array}$ & $\begin{array}{c}-80.8520 \\
{[-1.14]}\end{array}$ & $\begin{array}{l}-9.0527 \\
{[-11.35]}\end{array}$ & $\begin{array}{c}-9.1894 \\
{[-11.26]}\end{array}$ & $\begin{array}{l}-9.4201 \\
{[-11.23]}\end{array}$ \\
\hline $\mathrm{c}$ & 62.1931 & -43.6364 & -0.3624 & -0.6147 & -0.8862 \\
\hline
\end{tabular}

Computed by authors using Econometric view 5.0.

\subsubsection{Savings Function}

In the panel (a), (b) and (c) under the savings function; Central Bank policy rate, lending rate and deposit rate were interacted distinctly on savings. In panel (a), policy rate exert an inelastic and significant impact on savings whereas, in panel (c) deposit rate was found not to be significant in explaining changes in saving. This could have resulted from the inelastic nature of supply of deposits, as deposit rate might not be an incentive for savings.

The inelastic nature of long run estimate of the retail bank rates and policy rates to macroeconomic variables witnessed in table 7 and 8 can as well be supported by the slow and sluggish pass-through observed in table 6 .

\section{Recommendation and Conclusion}

The study examines the pass-through of Central Bank policy rate on commercial banks' retail rates and macroeconomic variables using the Johansen and Juselius maximum likelihood and Engle-Granger two step procedures to obtain the short run and long run estimates; the mean adjustment lag and Wald test were also employed to ascertain the asymmetric pass-through for the period 1970-2011. The study found an evidence of downward stickiness in pass-through as retail bank rates exhibit slow and sluggish responses to changes in policy rates. The robustness of this evidence was examined using an alternative technique in examining the effectiveness of monetary transmission process, the Impulse Response Function (IRF) and Variance Decomposition (VD) analysis also supported the evidence of sluggish and incomplete pass-through to retail rates.

The major thrust of the study centred on the pass-through of policy rate, that is, the effectiveness of monetary policy stance in achieving macroeconomic policy targets. The empirical analysis found evidence supporting stable long run stationary relationship between policy rate and the macroeconomic indicators, but the short run disturbances in the model are long lived as shocks are weakly adjusted in the equilibrium path. likewise, pass-through was not only incomplete both in the short and long run but exhibits pattern following a weak and extremely sluggish adjustment. The study also obtained the long run equation between the explanatory variables (money supply, exchange rate, policy rate, lending rate, deposit rate, current output and future output level) and macroeconomic indicators. The estimation process access the impacts of the policy rate, lending rate and deposit rate with restrictions in order to distinctly obtain the specific effects of the policy rate and retail bank rates on the macroeconomic variables considered. The Central Bank policy rate and lending rate were found to exert inelastic and significant variation on the level of investment. This might not be unconnected to the inelastic nature of demand for loan. In the same manner, the expected future output impacts significant elastic variation on the level of investment; this is consistent with economic reasoning an expectation of increased future output raises the current level of investment. Considering the savings and consumption function, similar trend witnessed in the investment function was found. The policy rate and retail bank rates induce a negative and significant effect on 
inflation, this finding is relevant for monetary authorities and policy makers as effective monetary policy transmission can be a useful instrument under inflation targeting policy. Likewise, current and expected level of output induce an inverse changes on inflation, thereby likely to curtail inflationary pressure. In this line, Policy makers need to introduce policies geared toward output expansion in the economy.

\section{References}

Ahumada, L., \& Fuentes, J. R. (2004). Banking industry and monetary policy: An overwiew. Banking Market Structure and Monetary Policy, Central Bank of Chile.

Aydin, H. I. (2007). Interest rate pass-through in Turkey. Research and Monetary Policy Department Working Paper, The Central Bank of the Republic of Turkey. No. 07/05.

Bernanke, B., \& Gertler, M. (1995). Inside the black box: The credit channel of monetary policy transmission. Journal of Economic Perspectives, 9(4). http://dx.doi.org/10.1257/jep.9.4.27

Borio, C. E. V., \& Zritz, W. (1995). The response of short-term bank lending rates to policy rates: A cross-country perspective. BIS Working Paper No. 27. Basel, Switzerland: Bank for International Settlements.

Christian, S., \& Sebastain, W. (2013). Assessing the determinants of interest rate transmission through conditional impulse response functions. IMF Working Paper WP/13/23.

Christopher, S. K., \& Thomas, W. (2006). Bank interest in the Euro Area. European Central Bank Working Paper Series No. 580.

Cotarelli, C., \& Kourelis, A. (1994). Financial structure, bank lending rates and financial structure in Italy. IMF Staff Papers, 41(4), 587-623.

Crespo-Cuaresma, J. (2004). Interest rate pass-through in New EU member status: The case of the Czech Republic, Hungary and Poland. William Davidson Institute, University of Michigan Business School, Working Paper, No 671.

De Bondt, G. J. (2005). Interest rate pass-through: Empirical result for the Euro area. German Economic Review, 6(1), 37-78. http://dx.doi.org/10.1111/j.1465-6485.2005.00121.x

Donnay, M., \& Degryse, H. (2001). Bank lending rate pass-through and differences in the transmission of a single EMU monetary policy. Discussion Paper No. 0117, Katholicke Universiteit Leuven Center for Economic Studies.

Egert, B., \& MacDonald, R. (2009). Monetary transmission mechanism in central and Eastern Europe: Surveying the surveyable. Journal of Economic Surveys, 23(2), 277-327. http://dx.doi.org/10.1111/j.1467-6419.2008.00563.x

Engle, R. F., \& Granger, C. (1987). Cointegration and error correction: Representation, estimation and testing. Econometrica, 55, 251-276. http://dx.doi.org/10.2307/1913236

Fuertes, A. M., \& Heffernan, S. (2009). Interest rate transmission in the UK: A comparative analysis across financial firms and products. International Journal of Finance \& Economics, 14(1), 45-63. http://dx.doi.org/10.1002/ijfe.366

Gambacorta, L. (2008). How do banks set interest rates? European Economic Review, 52(5), 792-819. http://dx.doi.org/10.1016/j.euroecorev.2007.06.022

Hendry, D. F. (1995). Dynamic Econometrics. Oxford: Oxford University Press. http://dx.doi.org/10.1093/0198283164.001.0001

Hofmann, B. (2003). EMU and the transmission of monetary policy: Evidence from business lending rates. ZEI University of Bonn.

Hofmann, B., \& Mizen, P. (2004). Interest rate pass-through and monetary transmission: Evidence from individual financial institutions' retail rates. Economica, New Series, 71(281), 99-123. http://dx.doi.org/10.1111/j.0013-0427.2004.00359.x

Johansen, S. (1988). Statistical analysis of cointegration vectors. Journal of Economic Dynamics and Control, 12, 231-254. http://dx.doi.org/10.1016/0165-1889(88)90041-3

John, M., \& Pokhariyal, G. P. (2013). Two stage interest rate pass-through in Kenya. Journal of Emerging Trends in Economics and Management Sciences, 4(1), 54-61. 
Kleimeier, S., \& Sander, H. (2006). Expected versus unexpected monetary policy impulses and interest rate pass-through in euro-zone retail banking markets. Journal of Banking \& Finance, 30(7), 1839-70. http://dx.doi.org/10.1016/j.jbankfin.2005.07.006

Kobayashi, T. (2008). Incomplete interest rate pass-through and optimal monetary policy. Department of Economics, Chukyo University.

Kwapil, C., \& Scharler, J. (2010). Interest rate pass-through, monetary policy rules and macroeconomic stability. Journal of International Money and Finance, 29(2), 236-51. http://dx.doi.org/10.1016/j.jimonfin.2009.06.010

Lowe, P., \& Rohling, T. (1992). Loan rate stickiness: Theory and Evidence. Research Discussion Paper, 9206, Reserve Bank of Australia.

Michel, C., \& Yan, Y. (2010). Interest rate pass-through in the central african economic and monetary community. International Journal of Business Management, 5(1), 31-41.

Mishkin, F. S. (1996). The channels of monetary transmission: Lessons for monetary policy. Banque de France, Bulletin, 27, 33-44.

Mojon, B. (2000). Financial structure and the interest rate channel of ecb monetary policy. ECB Working Paper Series, No. 40.

Nikoloz, G. (2011). Determinants of interest rate pass-through: Do macroeconomic conditions and financial market structure matter? IMF Working Paper WP/11/176.

Rocio, B., Hernando, V., \& Norberto, R. (2006). Interest rate pass-through in Colombia: A micro-banking perspective. Macro Modelling Department of Banco de la Republica.

Rousseas, S. (1985). A markup theory of bank loan rates. Journal of Post Keynesian Economics, 8(1), 135-44.

Scholnick, B. (1996). Asymmetric adjustment of commercial bank interest rates: Evidence from Malaysia and Singapore. Journal of International Money and Finance, 15, 485-496. http://dx.doi.org/10.1016/0261-5606(96)00016-2

Sebastian, R. (2003). Asymmetric interest rate pass-through from monetary policy: The role of bank regulation. Department of Economics, University of Notre Dame.

Sorensen, C. K., \& Werner, T. (2006). Bank interest rate pass-through in the Euro Area: A cross country comparison. ECB Working Paper No. 580.

Stiglitz, J., \& Weiss, A. (1981). Credit rationing in markets with imperfect information. American Economic Review, 71(3).

Svensson, L. E. O. (2003). What is wrong with taylor rules? Using judgment in monetary policy through targeting rules. Journal of Economic Literature, 41(2), 426-77. http://dx.doi.org/10.1257/002205103765762734

Tai, P. N., Sek, S. K., \& Har, W. M. (2012). Interest Rate Pass-Through and Monetary Transmission in Asia. Faculty of Accountancy and Management UniversitiTunku Abdul Kahman Bandar Sungai Long, 43000 Selango Malaysia.

Tobia, S., Thomas, H. W., Ramona, B., \& Sonke, S. (2012). Determinants of the interest rate pass-through of banks-evidence form German loan products. Discussion paper Deutsche Bundesbank No. 26.

Toolsema, L., Sturm, J., \& Dehaan, J. (2002). Convergence of pass-through from money market to lending rates in EMU countries: New evidence. University of Groningen, Centre for Economic Research, Netherlands. CCSO Working Papers.

Toolsema, L. A., Sturm, J. E., \& de Haan, J. (2001). Convergence of monetary transmission in EMU: New Evidence. Cesifo Working Paper No. 465.

Weth, M. A. (2002). The pass-through from market interest rates to bank lending rates in germany. Discussion paper 11/02 Economic Research Centre of the Deutsche Bunderbank.

Yildirim, D. (2012). Interest rate pass-through to turkish lending rates: A threshold cointegration analysis. Economic Research Center Working papers in Economics 12/07.

Notes

Note 1. Responses of bank retail rates to official policy rates. 
Note 2. A high interest rate pass-through or effective interest rate channel indicates high speed of long-run policy transmission from policy rates to retail banking rate-which implies more effective monetary, higher market perfect competition and higher degree of financial integration.

Note 3. These models postulate that households are not consumption smoothers and plan for an entire life-time consumption pattern. In such a framework, there can be limited role of monetary policy as the impact of interest rate shocks is muted. This assumption can only work in developed financial systems where there exist easy accesses to consumer credit which allow households to smoothen their consumption patterns.

Note 4. The final results of pass-through models, such as interest rate markups, long-term pass-through coefficients or the speed of interest rate adjustment.

Note 5. Furthermore, Yildrim (2012) found the degree of banks' reluctance to follow a fall in money market rates to vary across lending rates-suggesting the existence of sectoral heterogeneity.

Note 6. They estimated the determinants of interest rate pass-through of banks to German loan products.

Note 7. These economies include: Hong Kong, Indonesia, Korea, Malaysia, Philippines, Singapore, and Thailand.

Note 8. The dataset is divided into two sub-period of pre-crisis (Jan. 1988-Jan. 1997) and post-crisis (Jan. 1999-Jan. 2010).

Note 9. They examined the pass-through of the policy interest rate for Costa Rican economy for the period 1996-2007 using a non-linear asymmetric vector error correction model.

Note 10. According to Cottarelli and Kourelis (1994) interest rate stickiness means that in the presence of a change of money market rates, bank rates change by a smaller amount in the short run (short-run stickiness) and possibly also in the long run (long-run stickiness).

Note 11. in their respective studies, found a number of differences in the speed and magnitude of pass through among countries and argue that financial structure of the economy accounts for the stickiness in retail interest rate pass-through.

Note 12. the interest rate channel emphasised the importance of the banking sector in the transmission of interests while the credit channel focuses on the link that arise between financial institutions (banks) and the agents to which they lend (Bernanke and Getler, 1991). The credit channel consist of factors that propage the effects of interest channel through their impact on lending rates (Betancourt et al., 2006).

Note 13. They proposes that when setting policy, monetary authorities should take into account banks' behaviour under diverse economic conditions in the effectiveness of IRTM-which depends on banks' reaction to prevailing shocks in the economy.

Note 14. the interest rate channel becomes effective if commercial banks quickly transmit the changes in the monetary policy rate to their customers, otherwise, ineffective or interest rates are sticky.

Note 15 . This process describes the ways in which monetary policy impacts aggregate demand and prices by influencing the investment and consumption decisions of firms, households, and financial intermediaries, Samba and Yau (2010).

Note 16. These channels include interest rate, bank lending, balance sheet, asset prices, exchange rate, and expectation channels.

Note 17. Changes in interest rates or money supply.

Note 18. Retail rates on loans and deposits are set by the commercial banks.

Note 19. Which include Montiel 1991; Ghatak and Sanchez-Fung 2007. Montiel (1991) sees developing countries as characterized by underdeveloped financial markets with limited portfolio of financial assets available to the private sector; lack of organised securities markets; under-developed money markets; controlled interest rates and nonexistent equity market. Whether the Montiel assumptions still hold in spite of the fast evolving financial system remain an obvious question.

Note 20. Lending or deposit rates.

Note 21 . When $\gamma_{1}$ is unity, the pass-through from money market rate to retail interest rate is full or complete. On the other hand, if $0<\gamma_{1}<1$ the pass-through rate is incomplete. The incomplete rate implies that the demand elasticity of deposits and loans is incomplete and also the banks have some degrees of market power.

Note 22. Retail bank interest rates in less competitive or oligopolistic segments of the retail bank market adjust 
incompletely and only with a delay. Contrarily, bank interest rates set in a fully competitive environment respond quickly and completely (De Bondt, 2002; Laudadio, 1987).

Note 23. In a more complex model, investment can be related to factors other than the interest rate such as current and expected future output levels.

Note 24. This applies in the case of lending rate (Marrota, 2009).

Note 25 . When the parameter $\beta_{1}$ exhibits such behaviour, interest rate is said to be sticky.

Note 26. The process of achieving this is called. Error Correction".

Note 27. Likewise, the Granger Representation theorem states that if two variables; say retail rates and the central Bank policy rates are co-integrated, then their relationship can be expressed as an equilibrium error correction model.

Note 28. This coefficient is expected to be statistically significant with value ranging between zero and one and be negative-indicating that there are market forces at work to reinstate long run equilibrium following short run disturbances.

Note 29. Criticised the model in $i x$ above on the basis that it assumes the mean adjustment lag is symmetrical when the lending or deposit rates are beyond or less than their equilibrium level.

Note 30. Otherwise known as the asymmetrical adjustment.

Note 31. Immediate pass-through or impact multipliers.

Note 32. In fact the effectiveness of monetary policy weakens in the long run, especially with deposit rates.

\section{Copyrights}

Copyright for this article is retained by the author(s), with first publication rights granted to the journal.

This is an open-access article distributed under the terms and conditions of the Creative Commons Attribution license (http://creativecommons.org/licenses/by/3.0/). 